\title{
A Shifting Cultivation Method for Producing Papaya for Unripe Consumption in Northeast Thailand*
}

\author{
Rapatsa Junthasri \\ Rajabhat Maha Sarakham University, Maha Sarakham, Thailand
}

\begin{abstract}
This was a survey research using a questionnaire. The sample population was 40 farmers who produced papaya for immature or unripe consumption. They were questioned about their cultivation practices, including choice of planting locations, land preparation methods, seedling production, irrigation and fertilization methods, method of selecting female or hermaphrodite trees, seed selection methods, harvest methods, and marketing methods. In addition, data were collected from 40 sample trees on the farmers' fields in five locations in northeastern Thailand: Kalasin, Maha Sarakham, Roi Et, Mukdahan, and Khon Kaen provinces for three years (2012, 2013, and 2014). Data were recorded on yield (kilograms per hectare), mean fruit weight, mean flesh thickness, mean fruit length, sales price each month, and mean incidence of Papaya Ringspot Virus (PRSV). The data showed that the farmers joined together in groups to rent land for papaya production. The rental contracts lasted only about 18 months, for one production cycle, after which the groups of farmers would shift their cultivation to a new location to avoid buildup of pathogens. To minimize spread of PRSV, the farmers mostly chose locations that were surrounded by rubber plantations or forests and had adequate water supply. They reduced costs by producing their own seeds and using locally-available chicken manure as a fertilizer supplement. During the survey period (2012-2014), the price paid to farmers for unripe papaya ranged from a low of $1 \mathrm{baht} / \mathrm{kg}$ to a high of $10 \mathrm{baht} / \mathrm{kg}$, with the highest mean prices paid in April and November (reflecting high demand during holidays) and the lowest mean prices paid in July-August and February-March. Data on fruit quality and yield indicated that Kalasin Province had the most favorable climatic conditions for producing unripe papaya.
\end{abstract}

Keywords: carica papaya, sustainable farming, fruit production, farmer groups, culinary demand, Papaya Ringspot Virus

\section{Introduction}

In Thailand, domestic demand for papaya has risen steadily, both for unripe and ripe household consumption and for industrial processing, such as for making canned fruit, chili sauce, and tomato sauce; for use as a tenderizer in the canned meat and fish industry; and for leather and textile processing (Janthasri, 2007). In particular, unripe papaya is the main ingredient that cannot be done without for making "som tam", or green

\footnotetext{
* Acknowledgements: This research could not have been completed without financial assistance from the Thailand Research Fund and research facilities graciously provided by the Faculty of Agricultural Technology, Rajabhat Maha Sarakham University. Many thanks to Mrs. Valerie Suwanseree for assistance in English language editing.

Rapatsa Junthasri, Ph.D. (horticulture), associate professor, Rajabhat Maha Sarakham University, Maha Sarakham, Thailand.

Correspondence concerning this paper should be addressed to Rapatsa Junthasri, Department of Plant Science, Faculty of Agricultural Technology, Rajabhat Maha Sarakham University, Mueang District, Maha Sarakham Province 44000, Thailand.
} 
papaya salad, which is a staple dish enjoyed every day by most Thai consumers, especially those in the northeastern region. The major papaya production centers of northeast Thailand are in Pak Chong District in Nakhon Ratchasima Province; Kantharalak District in Sisaket Province; Thaphra District in Khon Kaen Province; and Huai Phueng District in Kalasin Province. There is still not enough papaya produced in these areas to meet the demand of consumers in northeastern Thailand, however, and more papaya has to be transported into the region from provinces in the central part of Thailand (Janthasri, 2007). In particular, the "Khaek Dam Dumnern" cultivar from Ratchaburi Province is more popular with makers of som tam than the "Khaek Dam Sisaket" papaya grown in the northeast, because the unripe flesh tends to be crispier and taste better than the local cultivar (Janthasri, 2007). At present, papaya production in the northeastern region and elsewhere in Thailand has dropped due to Papaya Ringspot Virus (PRSV) (Janthasri, 2004). PRSV is a problem in all the major papaya production centers and even for small-scale household growers. It is not possible to continue growing papaya in the same areas continuously because of accumulation of the pathogen (R. Janthasri \& K. Janthasri, 2005). The PRSV outbreak has had a negative impact on papaya supply for the unripe papaya consumption market and for industrial processing.

Most of the research on papaya published in Thailand has been about breeding efforts to try to introduce resistance to PRSV or to increase the quantity and quality of fruits. To the best of the knowledge, there have been no detailed studies about the factors of success or production systems that lead to better papaya yield in some areas compared to others. Also, there are few studies that focus specifically on papaya production for unripe papaya consumption. This study thus aims to provide information about methods for producing papaya for unripe consumption currently used by farmers in the northeastern region of Thailand, with an aim to help solve the problems of papaya shortages in a sustainable way and recommend practical solutions to farmers.

\section{Research Method}

\section{Papaya Production Methods}

This was a survey research. Forty farmers were selected, consisting of 10 farmers each in the four northeastern provinces of Kalasin, Maha Sarakham, Roi Et, and Khon Kaen. The farmers were interviewed to collect data on: (a) their choice of planting locations, land preparation methods, seedling production, and transplanting methods; (b) their irrigation and fertilization methods; (c) their method of selecting female or hermaphrodite trees; (d) their seed selection methods; (e) their harvest methods; and (f) their marketing methods.

\section{Papaya Production Results}

In addition, data on papaya production for unripe consumption were collected from 40 trees at five locations in northeastern Thailand, one site each in Kalasin, Maha Sarakham, Roi Et, Mukdahan, and Khon Kaen provinces for three years $(2012,2013$, and 2014). Data were recorded on yield (kilograms per hectare), mean fruit weight, mean flesh thickness, mean fruit length, sales price each month, and mean incidence of PRSV, using the scale of Prasartsee et al. (2009), as follows:

- Level $0=$ no symptoms; very good tolerance;

- Level 1 = very mild mottling, meaning yellow areas covering $1 \%-25 \%$ of the leaf area, with some ring spots on leaves but no perceptible symptoms on fruit, no bruises or streaks on petioles and stem; good tolerance; 
- Level 2 = mild to moderate mottling, meaning yellow areas covering $26 \%-50 \%$ of the leaf area, fruit mostly smooth with some ring spots, no bruises or streaks on petioles or stem; medium tolerance;

- Level 3 = mottling, meaning yellow areas covering $51 \%-75 \%$ of the leaf area, clear evidence of ring spots all over the fruit, and bruises or streaks on the petioles and stem; little tolerance;

- Level 4 = severe mottling, meaning yellow areas covering $75 \%-100 \%$ of the leaf area, deformed or brittle leaves up to severe leaf distortion with only the midrib visible, clearly seen ring spots all over the fruit, scabby spots, deformed fruit, rough outer peel and bitter, and grainy flesh; no tolerance.

\section{Statistical Analysis}

Differences in means were compared using Duncan's multiple range test (DMRT) (K. A. Gomez \& A. A. Gomez, 1984) via the MSTAT program (Bricker, 1989).

\section{Results and Discussion}

The papaya production methods used by sample farmers in the northeastern region for producing unripe papaya were different from previously reported methods for producing ripe papaya in terms of farm location, time of year for planting, and length of harvesting season. For producing green papaya for unripe consumption, the farmers surveyed began planting seedlings in April to June. When the rainy season began in July, they would prepare the land and transplant the seedlings. The papaya trees began to flower in August and the farmers selected hermaphrodite trees to keep. In September, they would thin the fruits down to two or three per tree in order to be able to collect larger fruit with a greater number of mature seeds. In the cool season in December, they collected the first fruits, which were all used for their seeds to grow the next year's crop. After that, the farmers would harvest unripe papayas up until the trees were 18 months old. This differs from the system normally used to produce ripe papayas. Ripe papaya production begins with transplanting seedlings in May to June, and it takes eight or nine months to harvest the first crop of ripe papayas, after which successive harvests of ripe fruits are made every seven to eight months, and a new set of trees will be planted after no more than two years in the same plantation area. By contrast, this survey revealed that the farmers producing papaya for unripe consumption in the northeast moved their plantation to a new plot of land for each new crop, following the system described below.

\section{Planting Area Selection/Land Preparation/Seed Planting/Transplanting}

Most of the farmers surveyed chose planting areas that had previously been used to grow sugar cane or cassava and had recently been harvested, because there would be some nutrients left in the soil from the fertilizers used on the sugar cane or cassava that would help nourish the papaya plants for a few months. They would rent the land for 18 months per crop and would constantly rotate the area used to plant papaya, avoiding using the same area twice. They believed that this practice would help reduce the severity of PRSV. Each family grew papaya on 1.6 to 3.2 hectares. Most families were allied with their relatives for papaya production and sales, so groups of four to five farming families would together rent eight to 16 hectares of land nearby each other for planting papaya. The areas they chose had to have sufficient water supply for growing papaya for 18 months and they would try to choose an area that was surrounded by forest and far from residential communities in order to reduce the prevalence of PRSV. The groups of families would start planting seedlings together in April to June, using seeds they collected from fruits of hermaphrodite trees from the previous season. They planted four-five seeds at a depth of $1 \mathrm{~cm}$ in $2 \times 6$ inch black plastic bags filled with a 2:3:1 mixture of 
topsoil: burnt rice husks: compost buffered with calcium hydroxide to deter microbes. They used metalaxyl (30 $\mathrm{g} / 20 \mathrm{~L}$ water) as a fungicide to prevent damping off. When the seedlings were 20 days old, they fertilized them with flaked fertilizer formula 25-5-5 (30 g/20 L water) and when they were 40 days old they transplanted them to the field (Janthasri \& Atiwetin, 2005).

\section{Maintenance/Irrigation/Fertilization}

To prepare the land, the farmers first plowed $30 \mathrm{~cm}$ furrows, similar to the method for growing cassava, and left the soil to dry in the sun for about two months. Then they prepared raised bed or berms for planting papayas at a spacing of $1.7 \times 1.7 \mathrm{~m}$ and dug holes $50 \mathrm{~cm}$ deep for each seedling, leaving the soil to dry for one week. They filled each hole with a 1: 1: 1 mixture of compost: burnt rice husks: rice husks, and to the mixture added $200 \mathrm{~g}$ of $15-15-15$ fertilizer for each hole. They initially planted two seedlings per hole and when the trees were four months old they selected only one hermaphrodite tree per hole to keep.

The farmers in the survey used sprinkler irrigation. The water was pumped with a four-horsepower pump into PE pipes set up in the field spaced about $2 \mathrm{~m}$ apart. They watered the seedlings every three days throughout the season.

The farmers surveyed used both chemical fertilizer and manure. About one month after the papaya seedlings had first been transplanted, they applied chemical fertilizer formula 15-15-15 at the rate of $100 \mathrm{~g} /$ tree each month, supplemented with manure. When the trees started to flower at about four months, they switched to formula 12-24-12, also administered at the rate of $100 \mathrm{~g} /$ tree; and when the trees were forming fruit at about six months, they used formula 13-13-21 at the same rate.

For manure, they used only chicken manure (obtained from egg farms in Nakhon Ratchasima Province). They applied manure four times per year, when the trees were forming new leaves (around two months), flowering (around four months), during the first fruit set (about six months), and at the time of the first harvest (about eight to nine months). Each time they applied $5 \mathrm{~kg}$ manure per tree.

As for weed control, the farmers in this area did not have serious weed problems, because their planting space was rather narrow at $1.7 \mathrm{~m}$ between trees and $1.7 \mathrm{~m}$ between rows. The papaya leaf cover prevented most sunlight from reaching the ground. They only needed to weed once about three to four months after the seedlings were transplanted, so this helped reduce their production costs.

\section{Selection of Hermaphrodite Trees}

The farmers selected hermaphrodite trees when the first set of flowers bloomed (at 3.5 months for "Yellow Krang" cultivar or four months for "Khaek Dam" and "Khaek Nuan" cultivars). Normally the first flowers of a papaya tree do not set fruit, but can be used to distinguish if the tree is male, female, or hermaphrodite. The farmers selected one hermaphrodite tree to keep out of the two planted in each hole, and pulled out the other, because fruits from hermaphrodite flowers tend to be the elongated shape that is preferred by consumers.

\section{Seed Selection}

The farmers selected trees that grew quickly and produced fruit true-to-type to use as seed for the next season. After the trees flowered, they would leave them to pollinate naturally, and after fruit set they would thin the fruits to no more than three per tree. The first fruits could be harvested in December and they would all be used for seed. Most of these first fruits were quite long and large, about $42 \times 60 \mathrm{~cm}$, and produced enough seeds for the farmers' needs. Producing their own seed helped the farmers save about $1 / 3$ of the production cost, because in the market, seeds cost one to four baht per seed. 


\section{Harvesting}

After collecting the first crop of ripe fruit for seed collection, the farmers fertilized the trees to stimulate flowering and to nourish the second crop of fruits, adding first 12-24-12 formula fertilizer and later 13-13-21 formula fertilizer at the rate of $100 \mathrm{~g} /$ tree. Starting from the second set of fruits, which could be harvested around March, the farmers would harvest all the fruits, while they were still green for unripe consumption (about five to six months after fruit set). They were able to harvest fruits every two weeks up until November, when they would cease harvest and move to a new growing location. In all, the farmers made about 20 harvests of unripe fruits from each set of trees. The data from three seasons $(2012,2013$, and 2014) showed that there were statistically significant differences in yield among the five sites surveyed in five provinces. Average yields in Kalasin, Mukdahan, and Maha Sarakham were higher than that in Khon Kaen and Roi Et (Table 1). In general, yield of papaya that is harvested when unripe, is higher than that of papaya that is harvested ripe. This may be because it requires less time for the fruit to mature and harvests can be made more frequently (Janthasri, 2014).

Table 1

Yield per Hectare and Mean Fruit Weight of Unripe Papaya ("Yellow Krang" Cultivar) Produced in Five Northeastern Provinces in 2012-2014

\begin{tabular}{lllllllll}
\hline \multirow{2}{*}{ Province } & \multicolumn{4}{c}{ Yield (kg/ha) } \\
\cline { 2 - 9 } & 2012 & 2013 & 2014 & Mean & 2012 & 2013 & 2014 & Mean fruit weight (kg) \\
\hline Khon Kaen & $77,321^{\mathrm{b}}$ & $70,916^{\mathrm{bc}}$ & $64,759^{\mathrm{b}}$ & $70,793^{\mathrm{b}}$ & $1.3^{\mathrm{b}}$ & $0.9^{\mathrm{c}}$ & $1.2^{\mathrm{b}}$ & $1.1^{\mathrm{c}}$ \\
Kalasin & $114,057^{\mathrm{a}}$ & $109,126^{\mathrm{a}}$ & $91,518^{\mathrm{a}}$ & $104,900^{\mathrm{a}}$ & $1.6^{\mathrm{b}}$ & $2.1^{\mathrm{a}}$ & $1.9^{\mathrm{a}}$ & $1.8^{\mathrm{a}}$ \\
Maha Sarakham & $97,280^{\mathrm{ab}}$ & $92,956^{\mathrm{b}}$ & $76,350^{\mathrm{ab}}$ & $88,862^{\mathrm{ab}}$ & $1.9^{\mathrm{a}}$ & $1.5^{\mathrm{b}}$ & $1.6^{\mathrm{ab}}$ & $1.6^{\mathrm{b}}$ \\
Roi Et & $61,321^{\mathrm{c}}$ & $61,976^{\mathrm{c}}$ & $53,654^{\mathrm{c}}$ & $58,982^{\mathrm{c}}$ & $0.8^{\mathrm{c}}$ & $0.7^{\mathrm{c}}$ & $1.1^{\mathrm{b}}$ & $1.8^{\mathrm{a}}$ \\
Mukdahan & $105,704^{\mathrm{ab}}$ & $99,964^{\mathrm{b}}$ & $75,041^{\mathrm{ab}}$ & $93,569^{\mathrm{ab}}$ & $0.9^{\mathrm{c}}$ & $1.5^{\mathrm{b}}$ & $1.2^{\mathrm{b}}$ & $1.2^{\mathrm{c}}$ \\
Significance & $* *$ & $* *$ & $* *$ & $* *$ & $* *$ & $* *$ & $* *$ & $* *$ \\
CV (\%) & 8.2 & 6.9 & 10.3 & 6.71 & 8.80 & 12.51 & 11.35 & 9.03 \\
\hline
\end{tabular}

Note. Mean values in the same column followed by different superscripts $\left({ }^{a},{ }^{b}\right.$, and $\left.^{c}\right)$ signify a statistically significant difference at 95\% confidence based on Duncan's Multiple Range Test (DMRT).

There were also statistically significant differences in mean fruit weight among the five sites. The fruits from Kalasin and Roi Et were on average heavier than those from the other sites, and those from Mukdahan and Khon Kaen were the lightest (Table 1). These findings are consistent with those of Chaiyaboon (2012), who found that Kalasin Province had suitable climate and topography for unripe papaya production, with cooler temperatures averaging $25-26^{\circ} \mathrm{C}$ and little difference between day and night temperatures. The climate factor probably contributed to making the papaya from Kalasin higher quality, with good fruit thickness and fruit length (Table 2).

\section{Marketing}

The groups of farming families were able to harvest about 2,000 $\mathrm{kg}$ of unripe fruit at a time, depending on season. In the monsoon season (around April), there was a high likelihood of damage from heavy wind and rain and during the cooler season (around November) harvests were usually the highest. When the farmer groups could supply $1,000 \mathrm{~kg}$ of fruit or more at a time, a wholesale buyer from Khon Kaen would take a truck to the farms to pick up the fruits; but if the harvest was less than $1,000 \mathrm{~kg}$ at a time, another buyer from the local district would pick up the fruits. In either case, the farmers did not have to transport the fruits themselves. The 
largest markets for unripe papaya are in Khon Kaen, Udorn Thani, and Roi Et provinces. The major traders in Khon Kaen and Udorn Thani buy most of their fruits from farmers in Kalasin and Mukdahan provinces and sell each truckload within about two days. The papaya in markets in Roi Et are supplied mostly by farms in Mukdahan and each truckload sells out in just one day, so the trucks go to the farms to buy more fruit every other day.

Some papaya growers in Kalasin can now export some of their fruits to the EU (England) for a guaranteed price of $10 \mathrm{baht} / \mathrm{kg}$. The price paid for papaya in each place depends on several factors, such as the distance of the farm from the market, the quality of the fruit, the volume of each sale, and consumer demand. As you can see in Table 3, the price paid to the farmers tends to rise and fall each month in different areas, depending partly on demand. In November, when most rice farmers get together to harvest their rice, demand for unripe papaya tends to increase as many farmers make som tam to eat with their neighbors and relatives who come to work at the rice harvest. Similarly, papaya prices tend to be high in April, when there is greater demand for som tam because of long holidays after the end of the school year and for Songkran or Thai New Year (Janthasri, 2014).

Table 2

Mean Flesh Thickness and Fruit Length of Unripe Papaya Produced in Five Northeastern Provinces in 2012-2014

\begin{tabular}{lllllllll}
\hline \multirow{2}{*}{ Province } & \multicolumn{4}{c}{ Flesh thickness $(\mathrm{cm})$} & \multicolumn{5}{c}{ Fruit length $(\mathrm{cm})$} \\
\cline { 2 - 10 } & 2012 & 2013 & 2014 & Mean & 2012 & 2013 & 2014 & Mean \\
\hline Khon Kaen & $2.1^{\mathrm{ab}}$ & $2.0^{\mathrm{ab}}$ & $1.9^{\mathrm{b}}$ & $2.0^{\mathrm{b}}$ & $48.2^{\mathrm{b}}$ & $46.1^{\mathrm{b}}$ & $49.7^{\mathrm{b}}$ & $48.0^{\mathrm{b}}$ \\
Kalasin & $2.4^{\mathrm{a}}$ & $2.3^{\mathrm{a}}$ & $2.4^{\mathrm{a}}$ & $2.3^{\mathrm{a}}$ & $55.7^{\mathrm{a}}$ & $52.6^{\mathrm{a}}$ & $53.2^{\mathrm{a}}$ & $53.8^{\mathrm{a}}$ \\
Maha Sarakham & $2.2^{\mathrm{ab}}$ & $2.1^{\mathrm{ab}}$ & $1.9^{\mathrm{b}}$ & $2.0^{\mathrm{b}}$ & $49.3^{\mathrm{b}}$ & $45.8^{\mathrm{b}}$ & $48.4^{\mathrm{b}}$ & $47.8^{\mathrm{b}}$ \\
Roi Et & $1.8^{\mathrm{b}}$ & $2.0^{\mathrm{ab}}$ & $1.9^{\mathrm{b}}$ & $1.9^{\mathrm{c}}$ & $41.0^{\mathrm{c}}$ & $43.7^{\mathrm{c}}$ & $42.1^{\mathrm{c}}$ & $42.2^{\mathrm{c}}$ \\
Mukdahan & $1.9^{\mathrm{b}}$ & $1.9^{\mathrm{b}}$ & $1.8^{\mathrm{b}}$ & $1.8^{\mathrm{c}}$ & $40.2^{\mathrm{c}}$ & $46.8^{\mathrm{b}}$ & $45.5^{\mathrm{c}}$ & $44.1^{\mathrm{c}}$ \\
Significance & $* *$ & $* *$ & $* *$ & $* *$ & $* *$ & $* *$ & $* *$ & $* *$ \\
CV (\%) & 2.33 & 10.41 & 8.96 & 10.20 & 9.13 & 9.57 & 5.50 & 4.10 \\
\hline
\end{tabular}

Note. Mean values in the same column followed by different superscripts $\left({ }^{\mathrm{a}},{ }^{\mathrm{b}}\right.$, and $\left.^{\mathrm{c}}\right)$ signify a statistically significant difference at 95\% confidence based on Duncan's Multiple Range Test (DMRT).

Table 3

Mean Price Paid to Farmers for Unripe Papaya ("Yellow Krang" Cultivar) Produced in Five Northeastern Provinces per Month, 2012-2014

\begin{tabular}{llllllllllllll}
\hline \multicolumn{10}{c}{ Province/month farm gate papaya price (baht/kg) } \\
\hline & Jan. & Feb. & Mar. & Apr. & May & Jun. & July & Aug. & Sep. & Oct. & Nov. & Dec. & Mean \\
\hline Khon Kaen & 3 & 2 & 2 & 8 & 5 & 3 & 2 & 2 & 3 & 5 & 7 & 6 & 4.0 \\
Kalasin & 4 & 4 & 4.5 & 10 & 6 & 4 & 2 & 2.5 & 4 & 8 & 10 & 9 & 5.6 \\
Maha Sarakham & 2 & 2.5 & 2 & 7 & 5 & 4 & 1 & 2 & 3 & 7 & 8 & 7 & 4.2 \\
Roi Et & 3 & 1.5 & 1 & 8 & 5 & 3 & 1.5 & 2 & 3 & 5 & 7 & 7 & 3.9 \\
Mukdahan & 4 & 3 & 4 & 10 & 5.5 & 3 & 2 & 3.5 & 3.5 & 8 & 10 & 9 & 5.4 \\
Mean & 3.2 & 2.6 & 2.7 & 8.6 & 5.3 & 3.4 & 1.7 & 2.4 & 3.3 & 6.6 & 8.4 & 7.6 & \\
\hline
\end{tabular}

\section{PRSV Tolerance}

For PRSV control, the farmers surveyed their fields every day. If they saw signs of the virus, such as crinkling at the edges of leaves, they would remove the infected tree and plant a new one to replace it. However, 
usually they did not find evidence of the disease until near the end of the production period or 16-18 months after transplanting, in which case they did not bother to remove the infected trees, but left them since they would be starting over again with a new crop in a new location soon anyway. The incidence of PRSV was also related to the choice of growing location. In addition to having a sufficient water supply, the farmers tried to choose growing locations that were located close to forested areas and far from residential communities. This is consistent with the findings of Janthasri (2011), who reported that when papaya was planted in enclosed areas surrounded by sugar cane, cassava, banana, or eucalyptus plantations, the incidence of PRSV was less than in situations where papaya was planted out in the open with no windbreaks or other crops around. From Table 4 you can see that PRSV was found the least in Kalasin and Mukdahan provinces. This is probably mainly because the planting sites in those provinces were surrounded by sugar cane and rubber plantations and very far from villages or communities. Nevertheless, the data collected on the incidence of PRSV do not necessarily reflect the actual existence of PRSV in the areas, because whether or not PRSV is reported depends on how quickly the farmer can detect the symptoms and whether or not action is rapidly taken to control the disease and prevent its spread once it is detected.

Table 4

Incidence (Percent) and Recorded Level of Papaya Ringspot Virus in "Yellow Krang" Papaya Produced in Five Northeastern Provinces for Unripe Consumption in 2012-2014

\begin{tabular}{lllllll}
\hline \multirow{2}{*}{ Province } & \multicolumn{3}{c}{ PRSV incidence (\%) } & \multicolumn{2}{c}{${\text { PRSV level }{ }^{1 /}}^{\prime}$} \\
\cline { 2 - 7 } & 2012 & 2013 & 2014 & 2012 & 2013 & 2014 \\
\hline Khon Kaen & $73.69^{\mathrm{b} 2 l}$ & $85.12^{\mathrm{b}}$ & $80.32^{\mathrm{b}}$ & $3.51^{\mathrm{b} 2 /}$ & $3.12^{\mathrm{b}}$ & $3.28^{\mathrm{b}}$ \\
Kalasin & $48.11^{\mathrm{c}}$ & $62.42^{\mathrm{c}}$ & $57.30^{\mathrm{c}}$ & $3.10^{\mathrm{b}}$ & $2.16^{\mathrm{c}}$ & $3.27^{\mathrm{b}}$ \\
Maha Sarakham & $83.19^{\mathrm{a}}$ & $87.15^{\mathrm{b}}$ & $80.07^{\mathrm{b}}$ & $3.90^{\mathrm{a}}$ & $4.29^{\mathrm{ab}}$ & $4.08^{\mathrm{a}}$ \\
Roi Et & $89.33^{\mathrm{a}}$ & $92.42^{\mathrm{a}}$ & $90.63^{\mathrm{a}}$ & $4.01^{\mathrm{a}}$ & $4.40^{\mathrm{a}}$ & $4.36^{\mathrm{a}}$ \\
Mukdahan & $55.37^{\mathrm{c}}$ & $67.88^{\mathrm{c}}$ & $62.12^{\mathrm{c}}$ & $3.62^{\mathrm{b}}$ & $4.80^{\mathrm{a}}$ & $4.58^{\mathrm{a}}$ \\
Significance & $* *$ & $* *$ & $* *$ & $* *$ & $* *$ & $* *$ \\
CV (\%) & 5.90 & 5.11 & 10.40 & 7.16 & 8.30 & 6.12 \\
\hline
\end{tabular}

Notes. ${ }^{1}$ Level of PRSV: level $0=$ no symptoms; level $1=$ yellow mottling covering $1-25 \%$ of the leaf area (minimal); level $2=$ yellow mottling covering $26-50 \%$ of the leaf area (mild to moderate); level $3=$ yellow mottling covering $51-75 \%$ of the leaf area, clear evidence of ring spots (severe); and level 4 = yellow mottling covering $75-100 \%$ of the leaf area, clearly seen ring spots all over the fruit, scabby spots, deformed fruit (very severe); ${ }^{2}$ is mean values in the same column followed by different superscripts $\left({ }^{\mathrm{a}},{ }^{\mathrm{b}}\right.$, and $\left.{ }^{\mathrm{c}}\right)$ which signify a statistically significant difference at $95 \%$ confidence based on Duncan's Multiple Range Test (DMRT).

\section{Conclusions}

The method for producing papaya for unripe consumption in northeast Thailand differs from the common practices for producing papaya for ripe consumption in several ways. One production cycle lasts 18 months. Seeds are started and seedlings are transplanted in April. The first fruits are harvested in November to December. From January to October, unripe fruits are harvested for sale every two weeks. The farmers were allied in groups of about 10 families and they were able to pool their harvests, so that buyers would come to collect the fruits from their farms, allowing the farmers to avoid extra transportation costs. One major factor of success that allowed the groups of northeastern farmers to reduce damage from disease (PRSV) was their selection of growing areas that were surrounded by forested areas and far from communities. The major feature of their production system that differed from other papaya production schemes was the strategy of renting land 
for the short term and then shifting their papaya cultivation to a new location after each production cycle. In the situation of northeast Thailand, where agricultural land is still reasonably plentiful, this may be a sustainable production system, because the land is subsequently used for other crops rather than being a monoculture of papaya. Also, the papaya farmers were able to reduce fertilizer costs somewhat by taking advantage of nutrients left in the soil in areas that had previously been used to grow cassava or other crops. Chicken manure was used as an economical supplement to chemical fertilizers.

There were statistically significant differences in yield, fruit thickness, fruit length, and incidence of PRSV among the five sites in which data were collected and over the three years of the study. The sites in Kalasin and Mukdahan provinces had the highest yield and greatest fruit weight and length, as well as lower incidence of PRSV than the other provinces. Kalasin Province appears to have the most favorable water sources, temperature and rainfall for papaya production, followed by Mukdahan, Maha Sarakham, Khon Kaen, and Roi Et, in that order.

\section{References}

Bricker, A. A. (1989). MSTAT-C user's guide. Cary, NC: Statistical Analysis System Institute Inc.

Chaiyaboon, W. (2012). Papaya production for unripe consumption in Maha Sarakham Province (Special problems research report of Rajabhat Maha Sarakham University, Maha Sarakham, in Thai).

Gomez, K. A., \& Gomez, A. A. (1984). Statistical procedures for agricultural research. New York: John Wiley \& Sons.

Janthasri, R. (2004). A study of papaya tolerance to papaya ring spot virus in Ubol Ratchathani Province (Research report of the School of Agriculture, Ubol Ratchathani University).

Janthasri, R. (2007). Commercial papaya (1st ed.). Ubol Ratchathani: Ubol Ratchathani University Press (in Thai).

Janthasri, R. (2011). Papaya cultivation management to reduce the spread of papaya ringspot virus (Research report of Faculty of Agricultural Technology, Rajabhat Maha Sarakham University, Maha Sarakham, in Thai).

Janthasri, R. (2014). The situation of "Krang” papaya production in Kalasin Province (Research report for the Thailand Research Fund, Bangkok, in Thai).

Janthasri, R., \& Atiwetin, P. (2005). Effects of 3 kinds of fertilizer on the growth of papaya for unripe consumption in Maha Sarakham Province (Research report of Rajabhat Maha Sarakham University, Maha Sarakham, in Thai).

Janthasri, R., \& Janthasri, K. (2005). Comparison of papaya cultivars' tolerance to Papaya Ring Spot Virus in Ubol Ratchathani Province. Ubol Ratchathani University Academic Journal, 8(1), 8-19.

Prasartsee, V., Khumcha, U., Prasartsee, C., Siriyan, R., Kiattiyot, S., Yupin, P., \& Gonsalves, D. (2009). "Khon Kaen 80" cultivar: A small papaya for ripe consumption and export (Research report of the Khon Kaen Plant and Factors of Production Service Center, Zone 3 Agricultural Research and Development Office, Department of Agriculture, Bangkok in Thai). 